\title{
The Influencial Factors on Counselling Effectiveness Using Decision-Making Tools in Selecting Long-Term Contraceptive Methods in Kendal District
}

\author{
Ana Sundari 1), Bhisma Murti1), Endang Sutrisna ${ }^{2)}$ \\ 1)Masters Program in Public Health, Sebelas Maret University, Surakarta \\ ${ }^{2)}$ Faculty of Medicine, Sebelas Maret University, Surakarta
}

\begin{abstract}
Background: One of the efforts to increase the usage of Long-term Contraceptive Methods is an effective counselling using decision-making tools. This counselling is very important to assist acceptors in making decisions and providing convenience to problem solving, behaviour changes or attitudes towards contraception. This study aimed to analyse the counselling effectiveness using decision-making tools in selecting methods of long-active reversible contraception.

Subjects and Method: This was an analytic observational study with case-control design. This study was conducted at District of Kendal, Central Java, from May 18 to August 18, 2016. Population of this study was the entire contraceptive acceptors who were at district of Kendal. The samples were as much as 100 people, 35 contraceptive acceptors in case group and 65 in control group using quota sampling technique. The exogenous variables were counselling on DecisionMaking Tools, self-efficacy, subjective norms, behaviour of women of reproductive age, ages of women of reproductive age, parity of women of reproductive age, levels of education of women of reproductive age. The endogenous variables were the usage of long-term contraceptive methods. The data were collected by a set of questionnaires and analyzed by path analysis.

Results: Age $\geq 35$ years old $(b=-2.19$; CI 95\%=-3.60 to $-0.77 ; \mathrm{p}=0.002)$, multiparity $(\mathrm{b}=-2.04 ; \mathrm{CI}$ $95 \%=-3.99$ to $-0.09 ; \mathrm{p}=0.040)$. Primary education level $(\mathrm{b}=-0.55 ; \mathrm{CI} 95 \%=0.12$ to $1.85 ; \mathrm{p}=0.359)$. There was a positive correlation between counselling and behaviour $(b=0.98$; $\mathrm{CI} 95 \%=0.12$ to 1.85; $\mathrm{p}=0.025)$. There was a correlation between counselling and efficacy $(\mathrm{b}=1.56$; $\mathrm{CI} 95 \%=0.62$ to 2.50 ; $\mathrm{p}=$ 0.001). There was a correlation between behaviour and participation in the long-term contraceptive methods $(b=4.02$; CI $95 \%=1.71$ to $6.34 ; \mathrm{p}=0.001)$. There was a correlation between self-efficacy and participation in the long-term contraceptive methods $(b=3.23$; CI 95\% $=0.71$ to $5.75 ; \mathrm{p}=0.012)$. There was a correlation between subjective norms and participation in the longterm contraceptive methods $(b=3.25$; CI 95\%=0.92 to $5.59 ; \mathrm{p}=0.006)$.

Conclusion: Counselling using decision-making tools influences behaviour and self-efficacy in using the long-term contraceptive methods indirectly.
\end{abstract}

Keywords: long-term contraceptive methods, counselling, decision-making tools

\section{Correspondence:}

Ana Sundari. Masters Program in Public Health, Sebelas Maret University, Surakarta.

Email: ana.sundari@yahoo.com.

\section{BACKGROUND}

$\overline{\text { Population and Family Planning are one of }}$ the major problems in Indonesia nowadays. Population explosion in the last recent years is difficult to control. Census of Population in 2010 indicated that the amount of Indonesian population had reached 237.6 millions souls. These numbers put Indo- nesia at the fourth place in the world after China, India and United States of America (Profil Kependudukan dan Pembangunan Indonesia, 2013).

One way to set distance between births and to limit the number of births is by using contraception to paralyse sperms and obstruct their paths to meet eggs so as 
pregnancies will not occur. Contraception has two methods. Those are the long-term contraceptive and short-term contraceptive methods. Long-term contraceptive devices are IUDs, implant, Female Sterilization and Male Sterilization (Witjaksono,2014).

Based on the data of Demographic and Health Survey in Indonesia (2012), the result indicated that the acceptors of longterm contraceptive methods were still low. It was proven by the dominant use of the short-term contraceptive devices, especially the injections which reached $31.9 \%$. Whereas, long-term contraceptive devices only reached $10.9 \%$. Those were IUDs at $4.9 \%$, implants at $2.8 \%$, female sterilization at $3.0 \%$, and male sterilization at $0.2 \%$ which was lower than the previous percentage that had reached $14 \%$. Long-term contraception is a prime necessity to suppress the population growth rate. According to Ahmed et al., (2012) contraception is an effective way to reduce maternal mortality in developing countries. One of the efforts to increase the acceptors of long-term contraception is using effective counselling in family planning and in selecting the methods of contraception which consists of benefits, side effects, advantages and disadvantages in each of the contraceptive methods (Allen, 2012).

Contraception counselling is a process of giving information about contraception and positive interactions between clients and counsellors to assist the clients in recognising their needs, choosing the best solutions and making the most appropriate decisions to the situations the clients are dealing with (Department of Ministry of Health, Republic of Indonesia 2011). A study conducted by Kim et al., (2005) concluded that decision-making tools played very important roles in the process of making decisions as information media on Family Planning which was associated with patients' conditions, increasing clients' involvements in the process of making decisions, and increasing clients' active communication, so as to reduce the dominance of service provider in assisting clients in making their decisions.

Based on the data from Women's Empowerment and Family Planning Agency of Kendal Regency recorded at the end of 2013, the rate of population growth was 1.09, it increased 0.35, active participants of Family Planning were 148.534 acceptors (79.07\%) with low acceptors of long-term contraceptive methods which was figured in percentage as $19.67 \%$, consisted of acceptors of IUDs (5.1\%), implants (11\%), Female Sterilization (3\%), and Male Sterilization (0.57\%). Most of the acceptors used shortterm contraceptive devices (80.33\%), which had higher risks to contraceptive failures and cost more to compare to the long-term contraceptive methods. The usage of contraceptive devices in the form of injections reached 56\%, Drop Out level was 13.37\%, unmet need was 10.93\% (ВРPКB Kabupaten Kendal, 2013).

This study aimed to analyse counselling effectiveness using decision-making tools in selecting the long-term contraceptive methods after controlling the influence of confounding factors.

\section{SUBJECTS AND METHOD}

This study was observational analytical. This study design was correlational which was intended to review and reveal the correlation between research variables. The data collection used was survey method in order to gain information on status of symptoms in time of the study implementation.

The approach of this study was case control to reveal the risk factors which were studied retrospectively by analysing causal relationship and using reverse logic, which 
is deciding the outcome first then identifying the cause (risk factor).

Path analysis was implemented in this study in order to acknowledge the influential factors that affected counselling effectiveness using decision-making tools in selecting long-term contraceptive methods. This study involved some exogenous variables which consisted of counselling on DecisionMaking Tools, self-efficacy, subjective norms, behaviour of women of reproductive age, ages of women of reproductive age, parity of women of reproductive age, levels of education of women of reproductive age. Whereas, the usage of long-term contraceptive methods were the endogenous variables.

This study took place at District of Kendal, Central Java from May to August 2016. Population in this study was the entire Family Planning acceptors who had been acceptors of long-term and short-term contraception. The source population was the entire family planning acceptors who had been acceptors of long-term and shortterm contraception within District of Kendal.

Samples of this study were taken from chosen population whose case characteristics were Family Planning acceptors using long-term contraceptive methods and willing to participate in this study. Whereas, the controls were Family Planning acceptors who did not use long-term contraceptive methods and had the intentions to participate in this study. Samples were taken using quota sampling technique.

The numbers of samples, according to Hair et al., quoted by Murti (2013), is the ratio of the numbers of research subjects to those of independent variables in multivariate analysis. It is recommended to be around 15 and 20 subjects for each independent variable. There were 4 independent variables used in this study, and 20 subjects were taken into account. Thus, there were 80 Family Planning acceptors (20 times 4 independent variables) plus $10 \%$, which was equal to 35 Family Planning acceptors as the case and 65 as the control. Therefore, the numbers of samples of this study were 100 .

The variables of this study consisted of exogenous variables (independent variables), it was the counselling using the help of Decision-making Tools, self efficacy, subjective norms, behaviour of women of reproductive age, ages of women of reproductive age, parity and levels of education of women of reproductive age. Whereas the endogenous variables (dependent variable) was the use of long-term contraceptive methods.

The data collection in this study used questionnaires to measure seven variables. They were the counselling using the help of decision-making tools, self-efficacy, subjective norms, behaviour of women of reproductive age, ages of women of reproductive age, parity and levels of education of women of reproductive age.

Validity test, according to Last (2001) quoted by Murti (2011), states that the validity of measurement is the degree of truth from a conclusion which is resolved from a study, influenced and valued on the basis of method of the study which is applied as the representative of samples of the study and the characteristics of population which consisted of content validity, face validity, construct validity and criterion validity. Because some of the instruments were standardised and the others were not, it was necessary to run validity and reliability tests in the source population and within samples. The data taken and in accordance to the measurement of the samples were as much as 15 Family Planning acceptors. Content relevance of a measuring instrument could be valued quanti- 
tatively, by correlating items of questions from a measuring instrument and then correlating each item with the entire items. Question items with correlation coefficient which were less than 0.20 should be taken out of the list or rewritten.

Reliability test on variable measurement implemented 2 reliability aspects: (1) Internal Consistency; and (2) Stability. The aspect of internal consistency referred to correlation between question items. Each of them was asked in order to measure an equal composite variable. All items should measure all of variety aspects homogenously from the same variables. Internal consistency would be quantitatively measured in this study from each of the composite variables. Those were: (1) Item-total Correlation and (2) Split-half Reliability. Based on the results of item-total correlation reliability test, they indicated that on the instruments to measure the variables of behaviour of long-term contraceptive methods, subjective norms of long-term contraceptive methods, self-efficacy and counselling, all of the values of $r$ as the results of the measurement were more than the value of $r$ in the referral table ( $\geq 0.20$ ). Therefore, the entire items of questions could be declared reliable. In this study, split-half reliability was implemented by rating the internal consistency (homogeneity) measurement which divided items randomly into two parts of measuring devices, then correlated those two parts. Split-half reliability in this study was gauged using Alpha Cronbach. This measuring device indicated an internal consistency if it had Alpha Cronbach $\geq 0.60$. The higher the number showed on the Alpha Cronbach, the more consistent it was the measuring device. In this study, each of the questions and statements in every variable were tested and passed because the results of Alpha Cronbach were all $\geq 0.60$.
To analyse the data, this study implemented confirmatory factor analysis, and to test the structural equation modelling, this study used path analysis. According to Murti (2015), the steps in analysing data using path analysis consist of: (1) Model Specification. There are eight observed variables in model specification. Those are counselling using decision-making tools, self-efficacy, behaviour of women of reproductive age, ages of women of reproductive age, parity, levels of education of women of reproductive age and the use of long-term contraceptive methods. (2) Model Identification by identifying the numbers of structural variables, endogenous variables, exogenousvariables, and parameter which subsequently will be estimated later. At this stage, the researcher counts the degree of freedom (df) which indicates that path analysis is doable. Path analysis could be implemented only if $\mathrm{df} \geq \mathrm{o}$. Should $\mathrm{df}=\mathrm{o}$, the path analysis model will be stated as identified. However, if $\mathrm{df}>\mathrm{O}$, the path analysis model will be stated as overidentified and if $\mathrm{df}<0$, path analysis model will be stated as underidentified.

\footnotetext{
RESULTS

Based on special characteristics of data, out of 100 subjects of this study, most of them were at the age of 20-35 years, which was $46.2 \%$, in the case group and most of subjects in control group were at above 35 years which was 60\%. The subjects' levels of education were Primary School at the biggest number for both groups: case and control which reached $73.8 \%$ and $68.6 \%$ respectively. Parity of the research subjects were primiparae for both: case group and control group which reached the percentage of $70.8 \%$ and $77.1 \%$ respectively. Counselling was given more to the subjects in the case group as much as $53 \%$ and those who did not get counselling in the control group
} 
were $94.3 \%$. Negative behaviour on the subjects was dominant in both groups: case and control which reached $78.5 \%$ and $97.1 \%$ respectively. High self-efficacy was dominant in the case group which reached $56.9 \%$, and low efficacy was in control group which was $97.1 \%$. The subjects' norms were dominant with unsupportive norms for both groups: case and control which were $75.4 \%$ and $97.1 \%$ respectively. Contraception was $100 \%$ used as part of long-term contraceptive methods in the case group.

\section{Specification}

Significant model was figured as correlation between variables to be analysed.

\section{Model Identification}

The numbers of structured variables were identified as the numbers of endogenous variables, exogenous variables and the parameters which would be estimated later on. Using the degree of freedom (df), a value of 6 was considered as over identified in path analysis. Thus, path analysis could only be done.

\section{Estimation}

Path analysis model was made based on a theory whereby suitability was checked and tested with the best correlation variable model which was made by gathering the sample data.

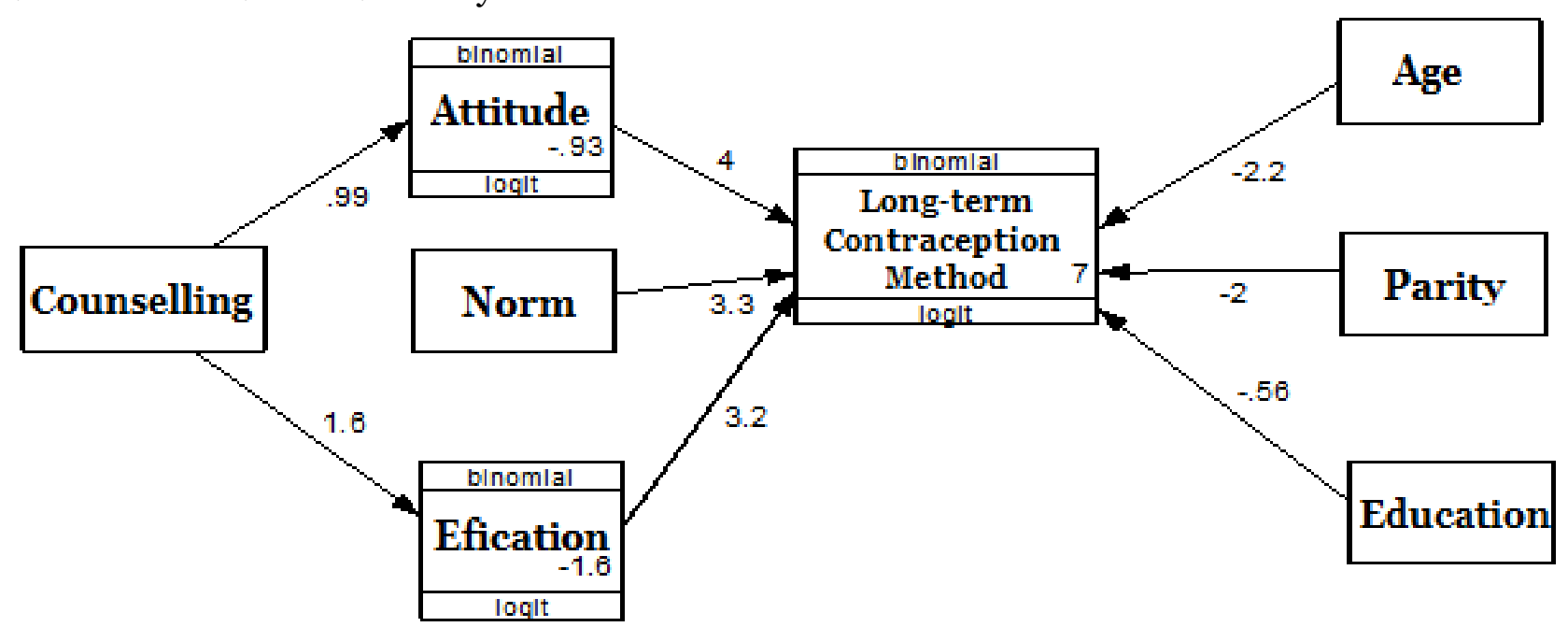

Picture 1. Structural Model and Estimation

Table 1. The results of path analysis' effectiveness of counselling using decisionmaking tools in selecting long-term contraceptive methods

\begin{tabular}{|c|c|c|c|c|c|c|}
\hline \multirow{2}{*}{\multicolumn{3}{|c|}{$\begin{array}{l}\text { Correlation between endogenous and } \\
\text { exogenous variables }\end{array}$}} & \multirow{2}{*}{ b } & \multicolumn{2}{|c|}{ CI $95 \%$} & \multirow[b]{2}{*}{$\mathbf{p}$} \\
\hline & & & & Lower Limit & Upper Limit & \\
\hline \multicolumn{7}{|c|}{ Direct Effect } \\
\hline Long-term & $\leftarrow$ & Behaviour & 4.02 & 1.71 & 6.34 & 0.001 \\
\hline Contraceptive & $\leftarrow$ & Efficacy & 3.23 & 0.71 & 5.75 & 0.012 \\
\hline \multirow[t]{4}{*}{ Methods } & $\leftarrow$ & Norms & 3.25 & 0.92 & $5 \cdot 59$ & 0.006 \\
\hline & $\leftarrow$ & Ages & -2.19 & -3.60 & -.775 & 0.002 \\
\hline & $\leftarrow$ & Parity & -2.04 & -3.99 & -.092 & 0.040 \\
\hline & $\leftarrow$ & Levels of Education & -0.55 & -1.74 & 0.631 & 0.359 \\
\hline \multicolumn{7}{|c|}{ Indirect Effect } \\
\hline Behaviour & $\leftarrow$ & Counselling & 0.98 & 0.12 & 1.85 & 0.025 \\
\hline Efficacy & $\leftarrow$ & Counselling & 1.56 & 0.63 & 2.50 & 0.001 \\
\hline N Observation & $=$ & 100 & & & & \\
\hline Log likelihood & $=$ & -147.12431 & & & & \\
\hline
\end{tabular}


Table 1 indicated that there was a correlation between counselling and behaviour with the increase of participation in the long-term contraceptive methods, and it was statistically significant. Women of reproductive age who had gotten counselling had logit function 0.98 times higher in positive behaviour than those who had not ( $b=0.98$; CI95\%=0.12 to $1.85 ; \mathrm{p}=0.025$ ).

Therewas a correlation between counselling and efficacy with participations in long-term contraceptive methods, and it was statistically significant. Women of reproductive age who had gotten counselling had logit function $\mathbf{1 . 5 6}$ times higher in selfefficacy than women of reproductive age who had not $(b=1.56$; CI95\%=0.62 to 2.50 ; $\mathrm{p}=$ 0.001).

Therewas a correlation between behaviour and participation in long-term contraceptive methods, and it was statistically significant. Women of reproductive age indicated positive behaviour had logit function of 4.02 higher to participate in longterm contraceptive methods than those indicated negative behaviour $(b=4.02$; CI $95 \%=1.71$ to $6.34 ; \mathrm{p}=0.001$ )

There was a correlation between efficacy and participation in long-term contraceptive methods, and it was statistically significant. Women of reproductive age with high self-efficacy had logit function of 3.23 to participate in long-term contraceptive methods. It was higher than Women of reproductive age with low self-efficacy $(b=$ 3.23; CI95\% $=0.71$ to $5.75 ; \mathrm{p}=0.012$ ).

Therewas a correlation between norms and participation in long-term contraceptive methods, and it was statistically significant. Women of reproductive age with agreed norms had logit function of 3.25 to participate in long-term contraceptive methods. This result was higher than women of reproductive age with disagreed norms $(b=3.25$; CI $95 \%=0.92$ to $5.59 ; p=0.006)$.
There was a correlation between ages and participation in long-term contraceptive methods. This correlation was statistically significant. Women of reproductive age who were older had logit function of 2.19 to participate in the long-term contraceptive methods. It was lower than women of reproductive age who were younger $(\mathrm{b}=$ 2.19; CI95\%= -3.60 to $-0.77 ; \mathrm{p}=0.002$ ).

There was a correlation between parity and participation in long-term contraceptive methods, and that correlation was statistically significant. Women of reproductive age with high parity had logit function of -2.04 to participate in long-term contraceptive methods. It was lower than women of reproductive age with low parity $(b=-2.04 ;$ CI $95 \%=-3.99$ to $-0.09 ; \mathrm{p}=$ 0.040).

There was a correlation between levels of education and participation in longterm contraceptive methods. This correlation was statistically insignificant. Women of reproductive age with high levels of education had logit function of -0.55 to participate in long-term contraceptive methods. It was lower than women of reproductive age with low levels of education $(b=$ -0.55 ; CI $95 \%=0.12$ to $1.85 ; \mathrm{p}=0.359$ ).

\section{Model Respecification}

Model in this study was in accordance with the sample data as shown by saturated model and regression coefficient which was valued more than a figure of zero to declared that it was statistically significant. Therefore, it was not necessary to remake path analysis model because it was a suitable model to the sample data.

\section{DISCUSSION}

\section{Correlation between age and parti- cipation in long-term contraceptive methods}

The results of this study indicated that there was a statistically significant corre- 
lation between the ages of women of reproductive age and the participation in longterm contraceptive methods. Women of non-reproductive ages had logit function of -2.19. It means that women of reproductive age have higher tendencies to participate in long-term contraceptive methods. This result of study is in accordance with the study previously conducted by Febriyani (2013) which indicated that most of the Family Planning contraceptive acceptors who were at the ages between 21-30 years old were as much as $70 \%$. Thus, if they do not use the contraceptive devices in a long-term basis, it can generate more opportunities for pregnancies.

A result on pre-experimental study conducted by Kostania et al., (2013) indicated that there was $66.7 \%$ women of reproductive age between 20-35 years old. Based on the data from the National Institution of Population and Family Planning (2011), it stated the fact that the targets of participants in the long-term contraceptive methods were meant to be for women of reproductive age or wives of childbearing age.

\section{Correlation between levels of edu- cation and participation in long- term contraceptive methods}

The result of this study indicated that there was a statistically significant correlation between levels of education of women of reproductive age and acceptors of longterm contraceptive methods. Women of reproductive age with higher levels of education had logit function of -0.55. It means that their participations in long-term contraceptive methods are lower than women of reproductive age with lower levels of education. The result of this study is in accordance with the previous one conducted by Yulizawati (2012). She came to a conclusion that there was no correlation between the research subjects' levels of education and the use of long-term contra- ception. Based on those results, an assumption is made that the cognitive levels of women of reproductive age are not only obtained from high levels of education, but also from learning processes throughout experiences and observing other people's behaviour. The result of this study is also associated with one of the concepts of cognitive theories according to Bandura. It is known as Reciprocal Entermininism whereby the behavioural changes can be determined from interactions between human beings and their environments.

\section{Correlation between parity and participation in long-term contra- ceptive methods}

The result of this study indicated that there was a statistically significant correlation between parity of women of reproductive age and the use of long-term contraceptive methods. Women of reproductive age with multiparity that had logit function of -2.04 had lower participation in long-term contraceptive methods than women of reproductive age with primiparae. It means that the more numbers of women of reproductive age with risky parity, the more they need well-planned pregnancies and labours. According to a previous study conducted by Kostania et al., (2013), mothers with parity of 1-2 children were the biggest numbers of rational contraceptive acceptors to as much as $93.3 \%$ in planning their longterm pregnancies. Parity that was more than 3 considered as a threat to reproduction systems and economy welfare.

\section{Correlation between counselling and behaviour to participation in long-term contraceptive methods}

The result of this study indicated that there was a direct and statistically significant correlation between counselling and behaviour to the increase of participation in long-term contraceptive methods. Women of reproductive age who had obtained coun- 
selling had a logit function of 0.98 times higher of positive behaviour than those women of reproductive age that had not. It means that counselling tends to show more positive behaviour from women of reproductive age toward the use of long-term contraceptive methods. It is also in accordance with a previous study conducted by Sheriar (2014). She came to a conclusion that counselling, which is structurally presented, and using instrumental devices that has become the operational standards, will cause a significant increase in selecting methods of modern contraception.

The implementation of counselling program influences the choices in contraceptive methods significantly (Costa et al., 2011). According to Davis et al., (1989 quoted by Jogiyanto 2008) behaviour is one's positive and negative feelings in implementing the designated behaviour. The result of the previous study indicated that behaviour influenced positively to the intentions. In this matter, counselling before becoming the acceptors of contraceptive devices influences behaviour of women of reproductive age towards the long-term contraceptive methods.

A study conducted by Yulizawati (2011) stated that behaviour had a significant correlation to the use of Intrauterine Devices (IUDs), whereby women of reproductive age with negative behaviour will not use IUDs to as much as 3.9 times when compared to women of reproductive age using IUDs. In other words, women of reproductive age with positive behaviour towards IUDs will have chances of 3.9 times for them to use IUDs.

5. Correlation between counselling and self-efficacy to participation in long-term contraceptive methods

The result of this study indicated that there was a statistically significant correlation between counselling and self-efficacy to parti- cipation in long-term contraceptive methods. Women of reproductive age that had been given counselling had logit function of 1.56 times to having self-efficacy which was higher than women of reproductive age that have not been given counselling. It means that by giving counselling women of reproductive age would have higher self-efficacy to the use of long-term contraceptive methods.

Baron and Byrne (2004) states that self-efficacy is an individual judgement to his ability and competence in implementing a task in order to reach a purpose or when solving problems. In this matter, women of reproductive age who have gotten counselling will increase their abilities in solving their own problems.

Behavioural maintenance can be done through assessments, equalities in all levels of interaction, from a family to society. In this matter, Bandura suggests some treatments, one of which is the exercise of mastery (desensitization modeling) by teaching the clients to master the behaviour that previously unable to do. This treatment can be acquired by giving counselling in longterm contraceptive methods.

\section{Correlation between behaviour and participation in long-term contraceptive methods}

The result of this study indicated that there is a statistically significant correlation between behaviour and participation in longterm contraceptive methods. Women of reproductive age with positive behaviour had logit function of 4.02 higher to participate in long-term contraceptive methods than women of reproductive age with negative behaviour $(\mathrm{b}=4.02$; $\mathrm{CI} 95 \%=1.71$ to 6.34; $\mathrm{p}=0.001$ ).

Based on the result of a previous study conducted by Yulizawati (2011) which indicated that behaviour had significant correlation to the use of IUDs, whereby 
women of reproductive age with negative behaviour would not use IUDs 3.9 times more than women of reproductive age who did. This means that positive behaviour from women of reproductive age will have the chances of 3.9 times more for them to use IUDs.

\section{Correlation between efficacy and participation in long-term contra- ceptive methods}

The result of this study indicated that there was statistically significant correlation between self-efficacy and the use of long-term contraceptive methods. Women of reproductive age with high self-efficacy had logit function of 3.23 to participate in the longterm contraceptive methods. It was higher than the women of reproductive age with low self-efficacy. This means that the higher the self-efficacy of women of reproductive age is, the bigger the willingness of women of reproductive age is in using the longterm contraceptive methods. It is in accordance with the cognitive theory suggested by Bandura (2001). He said that self-efficacy is a belief that someone could successfully implement behaviour. It means that with high self-efficacy or more self-confidence to the ability in doing behavioural changes, a person can try to do those changes easily with strong intensity to respond early failures than those with low efficacy.

Baron dan Byrne (2004) stated that self-efficacy was an individual judgement toward his ability and competence in doing a task to obtain goals or when solving problems. In this matter, women of reproductive age who have gotten counselling will increase their abilities to solve their problems.

\section{Correlation between subjective norms and participation in long- term contraceptive methods}

The result of this study indicated that there was statistically significant correlation bet- ween subjective norms and the use of longterm contraceptive methods. Women of reproductive age with good subjective norms had logit function of 3.25 higher to participate in long-term contraceptive methods than omen of reproductive age with not-good subjective norms. It means that the better the subjective norms of women of reproductive age are, the stronger the willingness is to use the long-term contraceptive methods.

Ajzen (1991) stated that subjective norms are the signs of functional existence to hopes which are individually perceived when one or more people around him (such as siblings or colleagues) agree to some certain behaviour and motivated the individual to obey them. In this matter, the norms of women of reproductive age in using long-term contraceptive methods are supported by their spouses, family and their surroundings.

Bhattacherjee (2000) views subjective norms as two forms of influence. Those are interpersonal influence and external influence. Interpersonal influence is the influence from friends, family members, coworkers, superiors and experienced individuals who are known as potential adopters. Whereas, external influence is influence from outside the organization, such as external reports from mass media, experts' reports and opinions, and other non-personal information which are considered in supporting the behaviour. This is in accordance to a previous result study which stated that the participations of women of reproductive age in long-term contraceptive methods were caused by the information women of reproductive age gained from counselling with decision-making tools.

The results of this study can be concluded that:

1. There is a correlation between age and participation in long-term contraceptive 
methods and such correlation is statistically significant $(b=-2.19$; CI95\%=-3.60 to -0.77 ; $\mathrm{p}=0.002)$.

2. There is a correlation between the levels of education and participation in long-term contraceptive methods, and that correlation is statistically significant $(\mathrm{b}=0.55$; $\mathrm{CI} 95 \%=$ 0.12 to $1.85 ; \mathrm{p}=0.359$ ).

3. There is a correlation between parity and participation in long-term contraceptive methods, and that correlation is statistically significant $(b=-2.04$; CI $95 \%=-3.99$ to $0.09 ; \mathrm{p}=0.040$ ).

4. There is a correlation between counselling and behaviour to the increase of participation in long-term contraceptive methods, and that correlation is statistically significant $(\mathrm{b}=0.98$; CI95\% $=0.12$ to 1.85 ; $\mathrm{p}=0.025$ ).

5. There is a correlation between counselling and efficacy to the increase of participation in long-term contraceptive methods, and that correlation is statistically significant $(b=1.56$; CI95\% $=0.62$ to $2.50 ; \mathrm{p}=$ o.001).

6. There is a correlation between behaviour and participation in long-term contraceptive methods, and that correlation is statistically significant (b=4.02; CI95\%= 1.71 to $6.34 ; \mathrm{p}=0.001$ ).

7. There is a correlation between efficacy and participation in long-term contraceptive methods, and that correlation is statistically significant $(b=3.23$; CI 95\% $=0.71$ to 5.75; $\mathrm{p}=0.012$ ).

8. There is a correlation between norm and participation in long-term contraceptive methods, and that correlation is statistically significant $(b=3.25$; CI $95 \%=0.92$ to 5.59 ; $\mathrm{p}=0.006$ ).

\section{REFERENCE}

Ahmed S, Li Q, MA, Liu l, Tsui AO (2012). Maternal deaths averted by contra- ceptive: An Analysis of 172 Countries. Lancet Journal. (380): 111-25.

Allen (2012). Contraception common issues and practical suggestion. Australian Family Physician. 40(10).

Ajzen I (1991). The Theory of Planned Behavior. Organizational Behavior and Human Decision Processes, 50 (2): 179-211.

Bandura A (2001). Theoretical Integration And Research Synthesis Essay. Social Cognitive Theory of Mass Communication. Department of Psychology Stanford University. Media psychology. 3: 265-299.

Bandura A (1997). Exercise of personal and collective efficacy in changing societies, in Bandura A. Self efficacy in changing societies, Cambridge University Pres, Cambridge: 1-45.

Baron R A dan Byrne D (2004). Psikologi sosial. Edisi terjemahan. Jakarta: Salemba empat.

BKKBN (2011). Pedoman pelaksanan pelayanan kontraspsi jangka panjang (MKJP) . Jakarta. BKKBN.

Costa AR, Palma F, Sá JL, Vicente L, Bombas T, Nogueira AM, Rocha $\mathrm{P}$ (2011). Impact of a women's counselling programme on combined hormonal contraception in Portugal - The IMAGINE study. Eur J Contracept Reprod Health Care.16:409-417.

Jogiyanto (2007). Sistem Informasi Keperilakuan, Yogyakarta: Andi Offset.

Kemenkes RI (2011). UU RI No 24 Tahun 2011 tentang Badan penyelenggara Jaminan Sosial.

Kim Y M, Adrienne K, Antonieta M, David S, Ward R, Sarah P, Sarah J and Kathryn C (2005). Promoting Informed Choice: Evaluating A Decision-Making Tool for Family Planning Clients And Providers in Mexico. 31(4). 
Journal of Medicine (2017), 2(1): 10-20

https://doi.org/10.26911/theijmed.2017.02.01.02

Profil Kependudukan dan pembangunan di Indonesia (2013). Profil kependudukan dan pembangunan di Indonesia. Diakses dari http://www.bkkbn.go.id. pada Desember 2015.

Sheriar N, Joshi R, Mukherjee B, Pal B, Birla A dan Ray SK, 2014. Impact of Structured Counseling on the Selection of Hormonal Contraceptive Methods: Results of a Multi-Centric, Observational Study in India. J Obstet Gynaecol India: 64(4): 241-250.

SDKI (2012). Survei Demografi dan Kesehatan Indonesia. Diakses dari http://- www.bppsdmk.depkes.go.id. pada Bulan Desember 2015

Witjaksono (2014). Kebijakan BKKBN dalam Meningkatkan Kesehatan Ibu dan Anak.Yogyakarta. Disampaikan dalam Pembukaan Program Studi Ilmu Kebidanan program Magister STIKES 'Aisyiyah Yogyakarta.

Yulizawati (2012). Analisis faktor yang berhubungan dengan peningkatan penggunaan alat kontrasepsi dalam rahim (AKDR) Bidan Prada: Jurnal Ilmiah Kebidanan. 3(2). 